\title{
Explicit, implicit and total taxes in the corporate sector: evidence for the Netherlands
}

Citation for published version (APA):

Janssen, J. B. P. E. C., \& Buijink, W. F. J. (2000). Explicit, implicit and total taxes in the corporate sector: evidence for the Netherlands. METEOR, Maastricht University School of Business and Economics. METEOR Research Memorandum No. 047 https://doi.org/10.26481/umamet.2000047

Document status and date:

Published: 01/01/2000

DOI:

10.26481/umamet.2000047

Document Version:

Publisher's PDF, also known as Version of record

\section{Please check the document version of this publication:}

- A submitted manuscript is the version of the article upon submission and before peer-review. There can be important differences between the submitted version and the official published version of record.

People interested in the research are advised to contact the author for the final version of the publication, or visit the DOI to the publisher's website.

- The final author version and the galley proof are versions of the publication after peer review.

- The final published version features the final layout of the paper including the volume, issue and page numbers.

Link to publication

\footnotetext{
General rights Owners
rights.

- You may freely distribute the URL identifying the publication in the public portal. please follow below link for the End User Agreement:

www.umlib.nl/taverne-license

Take down policy

If you believe that this document breaches copyright please contact us at:

repository@maastrichtuniversity.nl

providing details and we will investigate your claim.
}

Copyright and moral rights for the publications made accessible in the public portal are retained by the authors and/or other copyright owners and it is a condition of accessing publications that users recognise and abide by the legal requirements associated with these

- Users may download and print one copy of any publication from the public portal for the purpose of private study or research.

- You may not further distribute the material or use it for any profit-making activity or commercial gain

If the publication is distributed under the terms of Article $25 \mathrm{fa}$ of the Dutch Copyright Act, indicated by the "Taverne" license above, 


\title{
Explicit, Implicit and Total Taxes in the Corporate Sector: Evidence for the Netherlands
}

\author{
Boudewijn Janssen* \\ Willem Buijink* \\ version 3 \\ (preliminary, please do not quote)
}

MARC Working Paper MARC-WP/3/2000-09

"MARC and Department of Accounting and Finance, University of Maastricht, PO BOX 616, 6200 MD Maastricht, The Netherlands. Correspondence should be addressed to the first author: B.Janssen@berfin.unimaas.nl 


\begin{abstract}
This paper provides empirical evidence on the existence of implicit taxes in the corporate sector. With this finding, it provides support for the offsetting nature of explicit versus implicit taxes. Governments continuously provide tax preferences (tax incentives) to firms to induce these firms to alter their investment, production and financing decisions to reallocate resources towards outcomes that the government prefers. Tax preferences lead to lower explicit tax rates for firms that make use of these preferences. However (see Scholes and Wolfson (1992) and Wilkie (1992)), economic theory suggests that in equilibrium all firms must earn the same after-tax return (e.g. ROE). Hence high (low) implicit taxes (tax preference induced adjustments of pre-tax returns) can be expected for firms with low (high) explicit taxes. This paper uses financial statements of 123 listed firms for six years (19911996) to provide empirical evidence on the existence of implicit taxes in the corporate sector in the Netherlands. The paper finds that the inverse relation between implicit and explicit taxes exists, but is not a strong as expected, suggesting market frictions that prevent the equalisation of after-tax returns.
\end{abstract}




\section{INTRODUCTION}

Tax legislators (governments) continuously provide tax preferences (tax incentives or tax subsidies) to firms to induce these firms to alter their operating, investment or financing decisions to reallocate resources towards outcomes that the governments prefer as part of their economic policy.

Providing tax preferences to targeted firms creates the problem of tax equitability, i.e. whether firms are treated equally tax wise. Previous tax accounting research studied tax equitability by focusing on the Effective Tax Rate (ETR) measure. ETRs are often defined as tax charge divided by pre-tax accounting income. Thus, ETRs measure the amount of taxes payable by the company, the explicit taxes. However, this research has tended to overlook the fact that differences in explicit tax rates will, due to market competition, lead to implicit taxes, which are the differences between pre-tax returns on fully taxed investments and the pre-tax returns on partially or tax-exempt investments (Scholes and Wolfson, 1992, Wilkie, 1992). In fact, lower explicit taxes will thus lead to higher implicit taxes and vice versa. Therefore, equitable taxation would focus on equal total taxes across companies, including explicit and implicit taxes. Most research to date has focused on examining effective tax rates, while only a relatively small number of studies have investigated implicit taxes. The present paper will focus on explicit, implicit as well as total taxes. In doing so, this is the first study to use Dutch data and the first study investigating corporate implicit taxes in a cross-sectional design using a paired-sample design. By using this design, this paper avoids to a certain extent the pitfalls of controlling for risk and market friction.

Economic theory (see again, Scholes and Wolfson, 1992, Wilkie, 1992) suggests that in a competitive market the inverse association between explicit and implicit taxes should have a value of one. Put differently, in a competitive market the total tax burden, explicit and implicit, should equalise. Otherwise, arbitrage possibilities will be present. In the context of firms therefore, total taxes, explicit plus implicit taxes, should be equal across companies in a competitive market.

Note that, if total taxes are equal across companies, using (positive or negative) tax subsidies has no economic effect on companies, since tax preferences are replaced by implicit taxes (and vice versa for negative tax subsidies). 
In section two of this paper previous research will be addressed along with the conceptual model development. Section three operationalises the model and specifies the variables to be used, whereas section four will address the empirical methodology used in this paper. The results will be presented in section five. Finally, section six will provide a conclusion.

Note that below, like we did above, we will use the terms tax preference and tax subsidy interchangeably.

\section{PREVIOUS RESEARCH}

Previous empirical tax accounting research has assessed the importance of implicit taxes only to a limited degree. The theoretical framework was developed by Scholes and Wolfson (1992). Empirical studies that use it either investigate specific or corporate settings. Research on specific settings is in Stickney, Weil and Wolfson (1983), Scholes, Wilson and Wolfson (1990), Shackelford (1991) and Guenther (1994). Research in corporate settings is in Wilkie (1992), Callihan and White (1999) and Gupta and Weaver (1998). Corporate setting research was initiated by Wilkie (1992).

When discussing implicit taxes, the most important notion is the tax preference concept. Tax preferences are cross-sectional and intertemporal differences in the firms' exclusions, deductions, and other items that cause taxable income to diverge from pre-tax economic income (Wilkie, 1988). Due to the existence of positive or negative tax preferences, implicit taxes arise, since the marketplace will bid up the prices of tax-favoured investments, and thereby lower the pre-tax investments' returns (Scholes and Wolfson, 1992). Thus, implicit taxes are not paid (directly) to the tax authorities, but by the beneficiaries of these tax preferences. Implicit taxes on investments are defined as the difference between the before-tax return on a fully taxable investment and the before-tax return on a not-fully taxed investment (Scholes and Wolfson, 1992). Since investors will demand higher returns for riskier investments, these returns are riskadjusted.

An investor will thus not only pay explicit taxes, but also implicit taxes. In a competitive market, there should be a perfectly negative association between explicit and implicit taxes. The total taxes for an investment, that is explicit taxes plus implicit taxes, should be equal across 
investments (when controlling for non-tax costs); otherwise tax arbitrage possibilities will exist (Scholes and Wolfson, 1992). The framework of Scholes and Wolfson will be used later on to develop the model used in this paper.

In the first major paper to test this theoretical framework in a corporate setting Wilkie (1992) has empirically tested the implicit tax hypothesis by investigating the relationship between pre-tax return on equity and the pre-tax equivalent of tax-subsidies on equity. He finds a consistent and statistically significant inverse relation between pre-tax return and tax subsidy. However, the actual relationship found was weaker than hypothesised by the implicit tax hypothesis for a competitive market. But, Wilkie (1992) did not control for non competitive costs in his study. This omission might affect the strength of the relationship reported by Wilkie.

A number of other studies have also, to some extent, studied implicit taxes in a corporate setting. In an earlier study, Wilkie (1988) found that "ETR variations are caused by differences in both tax preferences and income whenever tax preferences and income are not perfectly correlated" (Wilkie, 1988), thereby providing support for the implicit tax hypothesis.

Studies focusing on specific settings include Stickney, Weil and Wolfson (1983) who, in a study of General Electric, found evidence supporting the implicit tax hypothesis regarding taxtransfer leases.

In another specific setting study, Scholes, Wilson and Wolfson (1990) found evidence of both implicit taxes and of non-tax costs in their study of changes in bank holdings of municipal bonds in response to tax rule changes regarding interest expense deductibility.

Using a different specific setting, Shackelford (1991), with regard to leveraged Employee Stock Ownership Plans (ESOPs), reported a similar finding. According to Shackelford most (but not all) of the tax benefits are shifted to the borrowers, thus providing support for both the implicit tax hypothesis as well as non-tax costs.

Combining an event study and the theoretical implicit tax concept, Guenther (1994) found evidence that changes in tax rates were linked with changes in pre-tax returns, regarding Treasury bills yields.

Recent research in the corporate setting is in Callihan and White (1999). Not only is the existence of implicit taxes researched, Callihan and White also use the firm's market power as a proxy for market inefficiencies. They find support for the existence of implicit taxes as well as for market structure differences relating to implicit taxes. 
Another recent study in a corporate setting is by Gupta and Weaver (1998), who investigate the existence of implicit taxes in the corporate sector, while taking into account time effects, specific tax legislation, industry membership and firm size. Their results also provide support for the existence of implicit taxes, though these do not appear to fully offset the explicit taxes.

Summarising the existing implicit tax accounting literature, previous studies have found evidence relating to the implicit tax hypothesis, although the associations found are not perfectly inverse as hypothesised, often due to the fact that the studies do not fully control for variation in risk and market frictions. .

The present study will focus not only on the association between explicit and implicit taxes, but will also investigate the level of total taxes across companies, while addressing two aspects which sofar have not been fully incorporated, risk and market frictions.

\section{CONCEPTUAL MODEL}

\subsection{ORIGINAL SPECIFICATION}

Scholes and Wolfson (1992) discuss the relationship between before- and after-tax returns on investment as follows. Let:

$\mathrm{R}_{\mathrm{b}} \quad$ be the return on fully taxed investments (the benchmark return);

$\mathrm{R}_{\mathrm{a}} \quad$ be the return on tax-exempt or partially taxed investments (the alternative return);

$t_{\text {Ia }}$ be the implicit tax rate on the alternative investment;

then Scholes and Wolfson state:

$$
\mathrm{R}_{\mathrm{b}}\left(1-\mathrm{t}_{\mathrm{Ia}}\right)=\mathrm{R}_{\mathrm{a}}
$$

Or, benchmark return minus implicit taxes is alternative return, for two different investments. Two assumptions underlying this model are the presence of competitive markets and the usage of risk-adjusted returns. Furthermore, this model also requires that one of the retunrs can be identified as the benchmark return (the fully taxed return). Let:

$\mathrm{I}_{\mathrm{a}} \quad$ be the implicit taxes; 
where $t_{I a}=I_{a} / R_{b}$; then equation (1) can be rewritten as:

$$
\mathrm{R}_{\mathrm{b}}-\mathrm{R}_{\mathrm{a}}=\mathrm{I}_{\mathrm{a}}
$$

for two investments. The implicit taxes, $I_{a}$, are the price investors have to pay for preferential (explicit) tax treatment. Tax preferences are the differences between taxable income and financial accounting income before taxes for a specific investment. Collectively, tax preferences are denoted tax subsidy. Furthermore, for one investment, there exists one return.

Since a company is the aggregate of a number of investments, the model can be extended to capture company differences. Let:

$\mathrm{R}_{\mathrm{c}} \quad$ be the company-specific return;

$\mathrm{t}_{\mathrm{Ic}} \quad$ be the implicit tax rate of the company

$\mathrm{I}_{\mathrm{c}} \quad$ be the implicit taxes of the company

then (2) can be rewritten as

(3) $\quad R_{c}=-t_{I c}+R_{b}$

for a specific company with risk-adjusted returns in a competitive market . Or:

(4) $\quad R_{c}=R_{b}-I_{c}$

Indicating that the (alternative) company return is equal to the benchmark return minus the implicit taxes. Now we introduce risk for both returns. Company risk will not directly affect implicit taxes, since implicit taxes arise out of tax preferences and are not due to company returns (Wilkie, 1988) as expressed in (5). Let:

$\mathrm{RF}$ be the risk factor

$$
\left(1+R F_{c}\right) R_{c}=R_{b}\left(1+R F_{b}\right)-I_{c}\left(1+R F_{i}\right)
$$

Now we also introduce market frictions, let:

$\mathrm{FR}_{\mathrm{c}}$ be the combined market frictions

(6) $\quad\left(1+\mathrm{RF}_{\mathrm{c}}\right) \mathrm{R}_{\mathrm{c}}+\mathrm{FR}_{\mathrm{c}}=\mathrm{R}_{\mathrm{b}}\left(1+\mathrm{RF}_{\mathrm{b}}\right)-\mathrm{I}_{\mathrm{c}}\left(1+\mathrm{RF}_{\mathrm{i}}\right)$ 
for two companies, with one benchmark return. In a cross-sectional setting we do not have a benchmark return, only cross-sectional returns. Replacing the benchmark return with another cross-sectional return, let:

$\mathrm{R}_{\mathrm{d}} \quad$ be the return of company $\mathrm{d}$

(7) $\quad\left(1+\mathrm{RF}_{\mathrm{c}}\right) \mathrm{R}_{\mathrm{c}}+\mathrm{FR}_{\mathrm{c}}=\mathrm{R}_{\mathrm{d}}\left(1+\mathrm{RF}_{\mathrm{d}}\right)-\mathrm{I}_{\mathrm{c}}\left(1+\mathrm{RF}_{\mathrm{i}}\right)$

which expresses the relationship of two cross-sectional returns considering risk and market frictions. 


\subsection{DUTCH CORPORATE INCOME TAX}

The Dutch financial accounting system follows the Anglo-Saxon model were there is a certain degree of independence between the determination of taxable income and financial accounting income. Therefore tax preferences can be deduced from financial statements.

Dutch tax preferences include: differences with regard to valuation of provisions, additional depreciation allowances, the existence of participation exemption, treatment of fiscal reserves and exchange rate differences. According to a study of the Dutch tax authorities (Belastingdienst, 1997), the participation exemption is the single most important tax preference in the Netherlands, being $53.1 \%$ of the total tax preferences in 1992 for the investigated sample. The existence of the participation exemption is caused by the Dutch corporate income tax system being a territorial tax system. Whereas a worldwide tax system (used by, among others, the USA) basically taxes worldwide income of a company, the territorial tax system only taxes profits accruing to the home country, exempting foreign country profits from home country taxation. Under the Dutch participation exemption, profits arising from participations in which the investor has an ownership of at least five percent, are untaxed. For holdings with foreign subsidiaries this effectively means that the foreign tax rate is the final tax rate for foreign profits, in contrast to the world-wide tax system where the home country tax rate is basically the final tax rate for all profits.

The current Dutch corporate income tax rate is 35 percent. In previous years, the first fl100,000.- or fl 250,000.- of taxable profits was taxed at various rates between 35 and 40 percent. However a statutory tax rate of 35 percent is assumed below.

\subsection{EXTENDED SPECIFICATION}

The first assumption underlying the theoretical framework is the usage of risk adjusted returns (Scholes and Wolfson, 1992).

The specific level of company risk will affect both the before- and after-tax rates of return, since investors will demand a higher return for more risky ventures and companies will increase their cost of capital with a risk surcharge. From (7) we have the following model: 


$$
\left(1+\mathrm{RF}_{\mathrm{c}}\right) \mathrm{R}_{\mathrm{c}}+\mathrm{FR}_{\mathrm{c}}=\mathrm{R}_{\mathrm{d}}\left(1+\mathrm{RF}_{\mathrm{d}}\right)-\mathrm{I}_{\mathrm{c}}\left(1+\mathrm{RF}_{\mathrm{i}}\right)
$$

To estimate this model, the following information is required:

- the before tax returns of companies $\left(\mathrm{R}_{\mathrm{c}}\right.$ and $\left.\mathrm{R}_{\mathrm{d}}\right)$;

- the risk level of companies $\left(\mathrm{RF}_{\mathrm{c}}\right.$ and $\left.\mathrm{RF}_{\mathrm{d}}\right)$;

- the amount of market frictions $\left(\mathrm{FR}_{\mathrm{c}}\right)$.

Previous cross-sectional research (Wilkie (1992), Callihan and White (1999) and Gupta and Weaver (1998)) has shown that it is difficult to directly control for risk and market frictions. In this paper we therefore use a design such that we do not have to control for differing risk levels and market frictions.

Firstly, if risk levels are the same for both firms, (7) simplifies to

$$
\mathrm{R}_{\mathrm{c}}+\mathrm{FR}_{\mathrm{c}}=\mathrm{R}_{\mathrm{d}}-\mathrm{I}_{\mathrm{c}}
$$

That is: a company's return $\left(\mathrm{R}_{\mathrm{c}}\right)$ plus the cost of market frictions $\left(\mathrm{FR}_{\mathrm{c}}\right)$ is equal to another company's return $\left(\mathrm{R}_{\mathrm{d}}\right)$ minus the implicit taxes. Implicit taxes in this setting can either be negative, positive or zero as neither of the returns is a benchmark return.

Secondly, if the company's are traded in a competitive market, no market frictions will be present and (8) can be simplified to (9):

(9) $\quad R_{c}=R_{d}-I_{c}$

That is, the before-tax return of a firm is equal to the before-tax return of another firm minus implicit taxes. The next section will detail how we try to eliminate risk differences and market frictions. 


\section{DATA, SAMPLE SELECTION, MODELS AND TESTS}

\subsection{RISK}

In order to be able to use model (9) where there are no risk differences between individual company returns, we first have to define the returns. As implicit taxes relate to earnings accruing to the owners of the company (being the shareholders), for the moment we define the returns of the company as the stock market returns. The risk of stock market returns can be measured by using beta, which reflects the risk of the company to the shareholders which are also the relevant title-holders to the company's profit. Furthermore, a company's beta reflects the risk of the combined investments or operations of the company. Now, by pairing firms with identical betas we can eliminate risk differences between companies.

\subsection{MARKET FRICTIONS}

Market frictions or deadweight costs are those frictions that prevent the market from functioning in a competitive manner. These frictions for instance include transaction costs. Although it is difficult to fully eliminate market frictions in the research design, we can eliminate transaction costs to some extent by only using companies in the research sample being traded on the same stock market (bearing, if any, the same relative market frictions) and in an active market segment (ensuring the lowest market frictions available in the stock market).

\subsection{METHODOLOGY}

To be able to measure the trade-off between explicit and implicit taxes without having to control directly for risk differences and market frictions, a paired sample design is used where each company is paired to another company with the same degree of risk (as captured by beta) and the lowest possible amount of market frictions (companies being traded in the most active segment of the Dutch stock market). In this paired sample design, the explicit tax rates should be negatively correlated with implicit taxes (tax preference induced adjustments of pre-tax returns). In an optimal setting with risk adjusted returns and absent market frictions this negative correlation 
should have a value of 1 , or, relative total taxes (explicit plus implicit taxes) across the paired observations should be the same.

In a situation where both firms have some implicit taxes, the relationship is:

(10) $\quad \mathrm{ETR}_{\mathrm{a}}+\mathrm{ITR}_{\mathrm{b}}=\mathrm{ETR}_{\mathrm{b}}+\mathrm{ITR}_{\mathrm{b}}$

where:

$\mathrm{ETR}_{\mathrm{a}, \mathrm{b}}=$ effective (explicit) tax rate of firm a,b respectively

$\mathrm{ITR}_{\mathrm{a}, \mathrm{b}}=$ implicit tax rate of firm a,b respectively

Let:

$\mathrm{TTR}_{\mathrm{a}, \mathrm{b}}=$ total tax rate of firm $\mathrm{a}, \mathrm{b}$ respectively

then:

(11) $\quad \mathrm{TTR}_{\mathrm{a}}=\mathrm{TTR}_{\mathrm{b}}$

or:

(12) $\quad \mathrm{TTR}_{\mathrm{a}}-\mathrm{TTR}_{\mathrm{b}}=0$

As it is unlikely that our research design fully eliminates risk differences and/or market frictions, we do not expect (12) to be true in the empirical setting. We therefore focus on the goodness of fit of the model for which we use model (10). Now we let the firm with the highest ETR be the benchmark return (in this case firm A), (10) simplifies to (13):

(13) $\quad \mathrm{ETR}_{\mathrm{a}}=\mathrm{ETR}_{\mathrm{b}}+\mathrm{ITR}_{\mathrm{b}}$

As the implicit tax rate for firm B is the difference between pre-tax returns of firms A and B, expressing (13) in pre-tax returns comes down to:

(14) $\quad \mathrm{ETR}_{\mathrm{a}}=\mathrm{ETR}_{\mathrm{b}}+\left([\operatorname{pretax} \operatorname{return} \mathrm{A}-\operatorname{pretax} \operatorname{return} \mathrm{B}]^{*}\left[1-\mathrm{ETR}_{\mathrm{a}}\right]\right) /$ pretax return $\mathrm{B}$ where the last term equals ITR $_{\mathrm{b}}$.

\subsection{ESTIMATION PROCEDURE}

To test (14) we use OLS regression estimates using the following regression equation: 
$\mathrm{y}_{\mathrm{i}}=\beta_{1 \mathrm{i}} \mathrm{ETR}_{\mathrm{b}}+\beta_{2 \mathrm{i}} \mathrm{ITR}_{\mathrm{b}}+\varepsilon_{\mathrm{i}}$

where:

$y_{i}=$ effective tax rate of firm a (the firm with the highest ETR in the pair) for observation $i$

$\varepsilon_{\mathrm{i}}=$ the error term

Note that as a result of (14) the regression equation should pass through the origin as a result of which no alfa is included in the regression equation.

\subsection{VARIABLE DEFINITION}

$\mathrm{ETR}=$

pre $=\operatorname{tax}$ return $=$

beta $=$

beta spread ? (20\%)

\subsection{DATASOURCE}

Data were obtained from the Worldscope database, which comprises information on over 17,000 companies worldwide. Data for the years 1991-1996 were collected for Dutch firms available on Worldscope. Worldscope only includes the largest Dutch firms (see below), whose information is transferred to a standard format enabling comparisons between companies. Due to data limitations, not all information in the standard format is filled out for Dutch companies. Thus, not all necessary data was available on Worldscope. In order to obtain those missing data, the Dutch CD-ROM datafile REACH was used, as well as annual reports of those companies. This additional data retrieving ensured that only a small number of companies had to be deleted from the final sample, due to missing data.

\subsection{SAMPLE SELECTION}


Only listed companies were included in the sample. Data for six years, 1991-1996 were used. From the original sample were excluded three categories of companies. Firstly, banks and insurance companies were deleted since these are subject to different accounting and tax rules. Secondly, only active companies were included, thereby excluding discontinued companies. Lastly, only companies with an industry template were included, thus effectively excluding investment companies and other financial institutions. A small number of companies had insufficient data, either because these were newly introduced companies, without having extended historical information, or they did not report (all of) the required data. The sample selection is reproduced in table 1 . 
Table 1: Sample selection.

Dutch companies available on Worldscope

Less: banks and insurance companies (SIC codes: 60,61,63,64)

Less: Inactive companies (i.e. discontinued or merged)

Less: companies with a non-industrial template

Less: newly introduced companies during sample period

Less: companies with insufficient data

Less: non listed companies

The companies included in the final balanced panel sample are listed in appendix A.

\section{RESULTS}

\subsection{DESCRIPTIVE AND UNIVARIATE RESULTS}

First, the companies' SIC-codes were recoded in 1-digit SIC-codes, in order to group the companies in several 1-digit SIC-codes. The results are reported in table 4. These results indicate that a majority of the sample firms are industrial companies (SIC-codes 1, 2 and 3). Table 5 provides descriptive information on the variables.

\section{Table 4: Sample companies classified on SIC-code.}

\begin{tabular}{clcr}
\hline SIC-category & Description (e.g.) & No. of companies & \% of companies \\
1 & Mining, extraction, building, and contractors & 10 & 8.1 \\
2 & Food products, textile, furniture, paper, & 32 & 26 \\
& chemicals, and petroleum & 33 & 26.8 \\
3 & Metal, industrial machinery, electrical & & 4.1
\end{tabular}


$5 \quad$ Wholesale trade and retail 28

$7 \quad$ Personal services and business services

Table 5: Descriptive information on the variable (data * / 1,000.-).

\begin{tabular}{lrrrr}
\hline Variable & Mean & $\mathbf{5 \%}$ trimmed mean & Median & Std. deviation \\
E & 81,196 & 20,640 & 8,321 & 386,805 \\
FTS & 36,031 & 14,595 & 2,960 & 125,111 \\
OPCF & 351,677 & 104,830 & 36,914 & $1,433,222$ \\
OPINC & 272,589 & 77,944 & 31,009 & $1,126,286$ \\
PTI & 257,281 & 74,304 & 32,096 & $1,114,263$ \\
TS1 & 36,031 & 14,596 & 2,960 & 125,111 \\
TS2 & 8,350 & 4,506 & 1,083 & 97,391 \\
TS3 & 2,992 & 3,902 & 460 & 64,712 \\
\hline
\end{tabular}

These results reveal that the data are right-skewed and platykurtic. It is interesting to note that both the return and tax subsidy measures based on cash flow are larger than their accrual counterparts. The mean of the three tax-subsidies variables is positive, indicating that the sample companies pay lower taxes than they ought to pay, based on the statutory tax rate.

To assess the associations between the variables correlations were computed. As the distribution of the data was nonnormal, the Spearman rho statistic was computed. Below, the correlations and their significance level are reported:

\begin{tabular}{llllllll}
\hline \multicolumn{7}{l}{ Table 6: Spearman correlations and significance. } \\
\hline \multirow{4}{*}{ E } & FTS & OPCF & OPINC & PTI & TS1 & TS2 & TS3 \\
& 0.137 & 0.800 & 0.878 & 0.891 & 0.320 & 0.218 & 0.268 \\
& $(0.130)$ & $(0.000)^{* *}$ & $(0.000)^{* *}$ & $(0.000)^{* *}$ & $(0.000)^{* *}$ & $(0.015)^{*}$ & $(0.003)^{* *}$ \\
FTS & & 0.232 & 0.272 & 0.241 & 0.180 & 0.338 & 0.257 \\
& & $(0.010)^{* *}$ & $(0.002)^{* *}$ & $(0.007)^{* *}$ & $(0.047)^{*}$ & $(0.000)^{* *}$ & $(0.004)^{* *}$ \\
\multirow{2}{*}{ OPCF } & & & 0.924 & 0.933 & 0.714 & 0.380 & 0.492 \\
& & & $(0.000)^{* *}$ & $(0.000)^{* *}$ & $(0.000)^{* *}$ & $(0.000)^{* *}$ & $(0.000)^{* *}$ \\
\multirow{2}{*}{ OPINC } & & & & 0.982 & 0.496 & 0.461 & 0.481 \\
& & & & $(0.000)^{* *}$ & $(0.000)^{* *}$ & $(0.000)^{* *}$ & $(0.000)^{* *}$ \\
\hline
\end{tabular}




\begin{tabular}{llll} 
PTI & 0.498 & 0.380 & 0.483 \\
& $(0.000)^{* *}$ & $(0.000)^{* *}$ & $(0.000)^{* *}$ \\
TS1 & & 0.344 & 0.481 \\
& & $(0.000)^{* *}$ & $(0.000)^{* *}$ \\
TS2 & & & 0.615 \\
& & & $(0.000)^{* *}$ \\
\hline
\end{tabular}

* Correlation is significant at 0.05 level; ** Correlation is significant at 0.01 level

Although not all correlations are substantial, most of them are statistically significant. The correlation between the cash flow return measure and tax subsidy based on cash flow is greater than the corresponding accrual correlations. This might indicate that cash flow data are 'cleaner' than accrual data.

\subsection{HYPOTHESIS ONE RESULTS}

The general linear model results constitute three models, one for each return measure. Using the recoded variables (except for the dummy variables) with application of effects-coding for the dummy SIC-codes, the following results for the three models were obtained (table 7).

\begin{tabular}{|c|c|c|c|c|c|c|}
\hline \multirow{3}{*}{\begin{tabular}{|l} 
Model: \\
Variable
\end{tabular}} & \multicolumn{6}{|c|}{$\begin{array}{l}\text { Rcj }="+\$ 1 T S c j+\$ 2 N C C c j+\$ 3 F T S c j+, ; \\
\text { where } c=\text { company }, j=\text { year }(1991-1996), \text { and } R=\text { OPCF, OPINC or PTI }\end{array}$} \\
\hline & \multicolumn{2}{|c|}{ OPCF } & \multicolumn{2}{|c|}{ OPINC } & \multicolumn{2}{|c|}{ PTI } \\
\hline & B & F-value & B & F-value & B & F-value \\
\hline TS & -4.729 & $22.986^{* *}$ & -3.7424 & $18.388^{* *}$ & -3.7883 & $8.190^{* *}$ \\
\hline FTS & 0.0702 & 0.437 & 0.1208 & 1.585 & 0.453 & 0.654 \\
\hline SIC1 & -0.376 & -0.448 & 0.177 & 0.201 & 0.389 & 0.350 \\
\hline SIC2 & -0.216 & -0.310 & 1.407 & 1.847 & 1.282 & 1.354 \\
\hline SIC3 & -0.942 & -1.386 & 0.172 & 0.216 & 0.007 & 0.008 \\
\hline SIC4 & -0.929 & -0.954 & -0.082 & -0.079 & -0.770 & -0.594 \\
\hline SIC5 & -0.138 & -0.211 & 0.281 & 0.383 & 0.644 & 0.697 \\
\hline SIC7 & -0.611 & -0.561 & 0.625 & 0.474 & 0.489 & 0.331 \\
\hline
\end{tabular}




\begin{tabular}{lllllll} 
SIC8 & -1.677 & -0.618 & 2.253 & 0.753 & 1.870 & 0.505 \\
Model: & \multicolumn{7}{c}{ : } & & & & \\
$\mathrm{R}^{2}\left(\operatorname{adj} \mathrm{R}^{2}\right)$ & 0.762 & $(0.703)$ & 0.711 & $(0.640)$ & 0.556 & $(0.447)$ \\
$\mathrm{F}$ & $13.043^{* *}$ & & $10.050^{* *}$ & & $5.115^{* *}$ & \\
\hline * significant at 0.05 level ** significant at 0.01 level
\end{tabular}

* significant at 0.05 level; ** significant at 0.01 level

All three models relating to hypothesis 1 are statistically significant at the 0.01 level. This statistical significance also holds true for the tax subsidy variable, but not for the foreign tax subject variable or the industry dummies. The variance captured by the models is quite high for the operating cash flow and operating income models with R-squares of $76.2 \%$ and $71.1 \%$ respectively, but lower for the pre-tax income model with a R-square of 55.6\%. Using these models hypothesis one can be confirmed. The results indicate that explicit and implicit taxes are negatively related.

The insignificant results for the SIC-dummies might be due to their too general 1-digit coding. To test for results on a more detailed industry level, 2-digit SIC coding was applied for categories that consisted of five or more companies. Eleven of these categories were present in the data set. Three of these categories did show significance in one or more of the models. Results for these categories are reported below.

Table 8: F-test values and significance levels for selected 2-digit SIC codes.

\begin{tabular}{lllllll}
\hline 2-digit code & OPCF & \multicolumn{3}{c}{ OPINC } & PTI & \\
\hline & F & Sign & F & Sign & F & Sign \\
\hline SIC 20 $^{1}(\mathrm{n}=9)$ & 3.320 & 0.071 & 7.317 & 0.008 & 3.406 & 0.068 \\
SIC 27 $(\mathrm{n}=5)$ & 4.141 & 0.044 & 4.492 & 0.036 & 10.418 & 0.002 \\
SIC 30 $(\mathrm{n}=7)$ & 6.160 & 0.015 & 1.555 & 0.215 & 2.762 & 0.100 \\
\hline
\end{tabular}

Only the F-values for SIC 27 are statistically significant at the 0.05 level for all models,

\footnotetext{
${ }^{1}$ SIC 20 represents food and kindred products, SIC 27 printing \& publishing and SIC 30 rubber and miscellaneous plastics products.
} 
but not at the 0.01 level. Although there is some support to suggest that certain industries have a different association between a company's return and its tax subsidy, the evidence is not structurally significant at the 0.01 level.

\subsection{HYPOTHESIS TWO RESULTS}

Using the results from the general linear model hypothesis two can be tested by the following simplified equation:

(II") $\quad \mathrm{t}_{\mathrm{s}} * \mathrm{R}_{\mathrm{cj}} \mathrm{BTS}_{\mathrm{cj}} \mathrm{BE}_{\mathrm{cj}}=0$

where NCC and FTS have been eliminated since these two variables were not statistically significant at the 0.01 significance level in the general linear model.

Since the variables were not normally distributed, the median test for two populations (Kanji, 1993) was performed, using our sample population and an expected population with median nil. The results for this test are reported in table 9.

Table 9: Median test results.

Model: $t_{s} * R_{c j} B_{T S} B_{c j}=0$; where $R=$ OPCF, OPINC, PTI

\begin{tabular}{lccc}
\hline Model & Test value & c.v. (0.10) & c.v. (0.01) \\
OPCF & 63.48 & 3.84 & 6.63 \\
OPINC & 66.42 & 3.84 & 6.63 \\
PTI & 63.48 & 3.84 & 6.63 \\
\hline
\end{tabular}

c.v. (0.10); c.v. (0.01): critical value of the $\mathrm{O}^{2}$ distribution with one degree of freedom for 0.10 and 0.01 significance levels (two-sided)

The large values of the test statistic enable us to reject the second hypothesis, stating that total taxes equal taxes the company ought to pay. In other words, implicit taxes are present, but the implicit taxes do not fully offset lower or higher explicit taxes. This may also be caused by inadequate control variables used in this design to measure market imperfections. Prior US tax accounting research usually did find industry differences relating to explicit tax burden (Effective Tax Rates). Our results using Dutch data do not support these findings with regard to implicit 
taxes. This may be due to differences between the US and Dutch tax system, inadequate SIC codes attached to the companies or shortcomings in our research design.

Furthermore, if Dutch companies' foreign tax rates are, on average, lower or higher than the Dutch statutory tax rate (35\%), this would affect the association between returns and implicit taxes. Our results do not provide support that foreign tax rates substantially differ from Dutch tax rates. This finding, however, is likely to be affected by a number of aspects. Higher foreign tax rates in some countries might offset lower foreign tax rates in other countries, thus effectively rendering our variable, foreign tax subject status, powerless. There could also be a discrepancy between the amount of sales in a particular country and the amount of taxable profit in this particular country. In this last instance, our foreign tax subject status variable should be measured by another proxy, preferable foreign taxable income relative to total taxable income. 


\section{CONCLUSION}

Tax legislators continuously provide firms with tax subsidies. Due to these tax subsidies companies pay lower explicit taxes. This would mean companies are not treated in an equitable manner. However, arbitrage possibilities will lead to implicit taxes for firms experiencing lower explicit taxes. Implicit taxes are the differences between the pre-tax returns of firms experiencing full explicit taxes and the pre-tax returns of firms with lower explicit taxes. Thus, empirical research in this paper first investigates to what extent implicit taxes are present in the Dutch context. Arbitrage possibilities will end when no further gains can be achieved by any of the involved parties. On a company level, this would be the case if the companies' total tax burden, including both explicit and implicit taxes, would be equal to the amount of taxes the company ought to pay when no tax subsidies would be available.

The second research question investigated in this paper is, whether explicit and implicit taxes fully offset each other. This offsetting is likely to be influenced by market imperfections. These market imperfections include timing differences between years, lack of competition (i.e. due to government regulation), and different tax rates between national tax systems. To address these market imperfections, a balanced panel sample of listed companies for six years is used, as well as proxies to measure the lack of competition and international differences in tax rates. Due to limited availability of data our proxies may not fully capture the expected market imperfections.

Our results confirm (1) the existence of implicit taxes for Dutch listed companies. Our model is however, not able to attribute market imperfections to industry differences and level of foreign activities. This may also provide an explanation for (2) our finding that taxes appear to be inequitable to some extent, as total taxes are not equal across companies. 


\section{REFERENCES}

Callihan, D.S., 1994, Corporate Effective Tax Rates: A synthesis of the literature, in: Journal of Accounting Literature, 13, pp. 1-43

Callihan, D.S., White, R.A., 1998, An application of the Scholes and Wolfson model to examine the relation between implicit and explicit taxes and firm market structure, in: The Journal of the American Taxation Association, vol. 21, no. 1 (Spring 1999), pp 1-19

Guenther, D. A., 1994, The relation between tax rates and pre-tax returns: Direct evidence from the 1981 and 1986 tax rate reductions, in: Journal of Accounting and Economics, 18 (3), pp. 379393

Gupta, S., Weaver, C.D., 1998, Empirical evidence on implicit taxes in the corporate sector, working paper

Kanji G.P., 1993, 100 statistical tests, Sage Publications, London

Scholes, M.S., Wilson, G.P., Wolfson, M.A., 1990, Tax Planning, Regulatory Capital Planning, and Financial Reporting Strategy for Commercial Banks, in: The Review of Financial Studies, 3 (4), pp. 625-650

Scholes, M.S., Wolfson, M.A., 1991, Taxes and Business Strategy: A Planning Approach, Prentice Hall, Englewood Cliffs

Shackelford, D.A., 1991, The market for tax benefits: Evidence from leveraged ESOPs, in: Journal of Accounting and Economics, 14, pp. 117-145

Stickney, C.P., Weil, R.L., Wolfson, M.A., 1983, Income Taxes and Tax-Transfer Leases: General Electric's Accounting for a Molotov Cocktail, in: The Accounting Review, 58 (2), pp. 439-459

Wilkie, P.J., 1988, Corporate Average Effective Tax Rates and Inferences about Relative Tax Preferences, in: The Journal of the American Taxation Association, pp. 75-88

Wilkie, P.J., 1992, Empirical Evidence of Implicit Taxes in the Corporate Sector, in: The Journal of the American Taxation Association, 14, pp. 97-116 


\section{APPENDIX A}

AALBERTS INDUSTRIES N.V.

AKZO NOBEL N.V.

ALANHERI NV

APOTHEKERS COOPERATIE OPG U.A.

ASM INTERNATIONAL N.V.

ATAG HOLDING N.V.

ATHLON GROEP NV

AXXICON GROUP NV

BALLAST NEDAM NV

BATENBURG BEHEER N.V.

BLYDENSTEIN-WILLINK N.V.

BROCACEF HOLDING NV

BURGMAN HEYBROEK NV

CAP GEMINI NV

CINDU INTERNATIONAL N.V.

CONTENT BEHEER NV

CROWN VAN GELDER PAPIERFABRIEKEN N.V. CSM N.V.

DE BOER WINKELBEDRIJVEN N.V.

DELFT INSTRUMENTS NV

DICO INTERNATIONAL NV

DRAKA HOLDING NV

DSM N.V.

ERIKS HOLDING N.V.

EUROPEAN MARKETING

INFORMATION SERVICES

FLEXOVIT INTERNATIONAL N.V.

FUGRO NV

GAMMA HOLDING NV

GELDERSE PAPIERGROEP NV

GETRONICS N.V.

GEVEKE N.V.

GOUDA VUURVAST HOLDING NV

GRAND HOTEL KRASNAPOLSKY NV

GRONTMIJ NV

HAGEMEYER N.V.

HEIDEMIJ NV

HEIJMANS NV

HEINEKEN N.V.
HELVOET HOLDING NV

HES BEHEER N.V.

HIM FURNESS NV

HOLLAND COLOURS NV

HOLLANDSCHE BETON GROEP NV

HUNTER DOUGLAS N.V.

IHC CALAND N.V.

INTERNATIO-MUELLER N.V.

KLENE HOLDING NV

KON NEDERLANDSCHE PETROLEUM

MAATSCHAPPIJ

KONINKLIJKE AHOLD NV

KONINKLIJKE AHREND NV

KONINKLIJKE BAM GROEP N.V.

KONINKLIJKE BOLSWESSANEN N.V.

KONINKLIJKE BOSKALIS WESTMINSTER N.V.

KONINKLIJKE ECONOSTO N.V.

KONINKLIJKE FRANS MAAS GROEP N.V.

KONINKLIJKE GIST-BROCADES N.V.

KONINKLIJKE GROLSCH NV

KONINKLIJKE HOOGOVENS NV

KONINKLIJKE LANDRE \& GLINDERMAN N.V.

KONINKLIJKE NEDLLOYD N.V.

KONINKLIJKE NEDSCHROEF HOLDING NV

KONINKLIJKE PAKHOED N.V.

KONINKLIJKE PTT NEDERLAND NV

KONINKLIJKE TEN CATE N.V.

KONINKLIJKE UBBINK N.V.

KONINKLIJKE VAN OMMEREN N.V.

KONINKLIJKE VOLKER WESSELS STEVIN NV

KOPPELPOORT HOLDING N.V.

KUEHNE \& HEITZ NV

LCI COMPUTER GROUP NV

MACINTOSH RETAIL GROUP NV

MULDER BOSKOOP NV

MULTIHOUSE N.V.

N.V. HOEK'S MACHINE- EN ZUURSTOFFABRIEK

N.V. KONINKLIJKE PORCELEYNE FLES

N.V. KONINKLIJKE SPHINX GUSTAVSBERG 
N.V. VERENIGDE BEDRIJVEN NUTRICIA NAEFF NV

NAGRON NATIONAAL GRONDBEZIT N.V. NBM-AMSTELLAND N.V.

NEDCON GROEP NV

NEWAYS ELECTRONICS NTERNATIONAL NV

NKF HOLDING N.V.

NORIT N.V.

NV HOLDINGMAATSCHAPPIJ DE TELEGRAAF NV KONINKLIJKE BIJENKORF BEHEER KBB NV KONINKLIJKE KNP BT NV NEDERLANDSCHE APPARATENFABRIEK NEDAP

NV VERENIGD BEZIT VNU

ORDINA BEHEER NV

OTRA N.V.

$P$ \& C GROEP NV

PHILIPS ELECTRONICS N.V.

POLYGRAM N.V.

POLYNORM N.V.

RANDSTAD HOLDING N.V.

REESINK N.V.

ROOD TESTHOUSE INTERNATIONAL NV

ROTO SMEETS DE BOER NV

ROYAL PACKAGING INDUSTRIES VAN LEER B.V.
RUBBER CULTUUR MAATSCHAPPIJ AMSTERDAM NV

SAMAS-GROEP N.V.

SCHUITEMA N.V.

SCHUTTERSVELD N.V.

SIMAC TECHNIEK NV

SLIGRO BEHEER NV

SMIT INTERNATIONALE N.V.

SMIT TRANSFORMATOREN NV

STORK NV

TEXTIELGROEP TWENTHE NV

TULIP COMPUTERS N.V.

UNILEVER N.V.

UNIQUE INTERNATIONAL NV

VAN DER GIESSEN-DE NOORD NV

VAN DORP DESPEC GROEP N.V.

VAN MELLE NV

VENDEX INTERNATIONAL N.V.

VILENZO INTERNATIONAL NV

VREDESTEIN N.V.

WEGENER N.V.

WELNA N.V.

WEWELER N.V.

WOLTERS KLUWER N.V. 